\title{
Studies of Pulmonary Blood Volume in Man \\ Effect of Amyl Nitrite
}

\author{
Nobuharu Akatsuka, M.D.
}

\section{SUMMARY}

The pulmonary blood volume was measured in the normal and in patients with mild mitral stenosis and coronary heart disease. The pulmonary blood volume in the normal was $360 \mathrm{ml} . / \mathrm{M} .^{2}$, in the mitral stenosis $440 \mathrm{ml} . / \mathrm{M}^{2}{ }^{2}$ and in the coronary heart disease $374 \mathrm{ml} . / \mathrm{M} .{ }^{2}$, respectively.

The inhalation of amyl nitrite resulted in an increase in cardiac index (normal $+50 \%$, mitral stenosis $+23 \%$, coronary heart disease $+40 \%$ ) and a decrease in the peak-to-peak time (normal - 35\%, mitral stenosis $-20 \%$, coronary heart disease $-16 \%$ ) in each group. The pulmonary blood volume after the inhalation did not change significantly in the normal $(-7 \%)$ and in the mitral stenosis $(-7 \%)$, and increased significantly in the coronary heart disease group $(+19 \%)$.

A positive vasodilating effect of amyl nitrite on the pulmonary vasculature was not recognized in this study.

\section{Additional Indexing Words:}

Pulmonary circulation Radiocardiography Peak-to-peak time Normal subjects Mitral stenosis Coronary heart disease

DULMONARY congestion is one of the most prominent manifestations of 1 mitral stenosis, left ventricular failure and renal failure. It has beens estimated semiquantitatively by physical signs and X-ray findings. Quantitative evaluation of pulmonary blood volume (PBV) in man had not been achieved until 1955 when Kunieda ${ }^{1)}$ measured PBV using a dye-dilution technique by sampling blood from the left atrium combined with right heart catheterization. Milnor, ${ }^{2}$ Dock ${ }^{3)}$ and Levinson ${ }^{4}$ also calculated PBV by similar methods. However, combined left and right heart catheterization is not convenient clinically in cases with pulmonary congestion or with pulmonary edema notwithstanding the report by Schreiner et al. ${ }^{5)}$ More recently, radiocardiography (RCG) using the external scintillation detector has been introduced as a practical method to estimate PBV.6) Although many studies have been done in this field, sufficient information is as yet not available about PBV except that in mitral stenosis.

From the First Department of Internal Medicine (Director: Prof. Y. Yoshitoshi), Faculty of Medicine, University of Tokyo, Tokyo.

Received for publication April 18, 1969. 
In this study, PBV in normal subjects, and in patients with coronary heart disease and with mitral stenosis were estimated by RCG in the resting state and after the inhalation of amyl nitrite. Although the characteristic effects of amyl nitrite on the pulmonary vascular pressure or resistance have been reported, the influences on PBV have not yct been published. The effects of amyl nitrite on pulmonary circulation and the mechanism of these changes will be briefly discussed.

\section{Materials AND Methods}

The cardiac output and the pulmonary blood volume before and after the inhalation of amyl nitrite were determined by external radiocardiography. I I31 albumin was used in most cases as an indicator. The initial dose of $I^{131}$ albumin was 10 to $20 \mu \mathrm{Ci}$ in 0.1 to $0.2 \mathrm{ml}$., and the following dose was 3 times as much as the initial dose. The total dose injected did not exceed $100 \mu \mathrm{Ci}$ in each subject. In some cases, tecnetium was used. In these cases, the initial dose was 50 to $100 \mu \mathrm{Ci}$ in 0.1 to $0.2 \mathrm{ml}$., and the following dose was 3 times as much as the initial dose. The indicator was injected into the left basilic or cephalic vein instantaneously using an 18 gauge needle, followed by a $10 \mathrm{ml}$. saline flush.

The collimated scintillation detector was placed vertically over the midsternal line at the level of the fourth rib at a distance of $1 \mathrm{~cm}$. from the skin. The timeconcentration curve obtained was plotted on semilogarithmic graph paper. The area under the curve $\left(\int_{c a}^{t d} C d t\right)$ was calculated by the Lilienfield-Kovak method. The end-tail concentration (Ceq) was used for calibration and was determined from well-mixed peripheral venous blood by a Well-type scintillation counter.

The cardiac output was calculated as follows:

$$
\text { C.O. }=\frac{C e q \times V \times 60}{\int_{t a}^{t d} C d t}
$$

where $\mathrm{V}:$ injected isotope (counts $/ \mathrm{min}$.)

Ceq: end-tail concentration (counts/min.)

$\int_{t a}^{t d} C d t:$ area under time-concentration curve

The pulmonary blood volume (PBV) was calculated by multiplying the cardiac index (C.I.) by the peak-to-peak time (P-P time). The reason why the P-P time was used will be discussed later.

All observations were made with the subjects supine. The reproducibility of radiocardiogram was examined on 6 hypertensives. Twenty sec. of amyl nitrite inhalation from a broken phial was performed about $10 \mathrm{~min}$. after the control radiocardiography. The second radiocardiogram was obtained at 30 sec. after the beginning of the inhalation of amyl nitrite. The normal control values were obtained from 10 subjects. The inhalation studies were made on 5 normal subjects, 9 patients with mild mitral stenosis and 13 patients with coronary heart disease. 
The P-P time was determined as follows. The first, in cases in which 2 peaks were easily recognized, P-P time was measured from peak to peak literally. The second, in cases in which only the right heart peak was recognized and the left heart peak was not clearly recognized, P-P time was obtained from the separated right and left heart curves on semilogarithmic graph paper. The mean transit time is obtained from the difference of the left and the right heart ejection times. Therefore, the volumes of the right and the left heart cavity and the ejection rate of the left heart have a considerable effect on the mean transit time. It was thought that the P-P time and the mean transit time in the cases in good cardiac condition and without enlargement of the cardiac chambers did not exhibit much difference. However, the mean transit time in the cases with impaired cardiac function with enlarged cardiac chambers revealed a marked elongation. The P-P time was obtained from the appearance times of the maximal concentration of the indicator in the right and the left chambers. Therefore, the P-P time was less influenced by the mixing chambers. Because of the above mentioned reason, the pulmonary blood volume calculated with the P-P time was thought to be closer to the real pulmonary blood volume than that calculated with the mean transit time.

\section{Results}

\section{Reproducibility}

Reproducibility was examined on 6 hypertensives. RCG was repeated twice in 5 to $10 \mathrm{~min}$. on each subject. The mean C.I. was $4.8 \mathrm{~L} . / \mathrm{min} . / \mathrm{M.}^{2}$, with a range of 3.3. to $6.3(\mathrm{~s}=1.25)$ for the first time, and was $4.9 \mathrm{~L} . / \mathrm{min} . / \mathrm{M.}^{2}$, with a range of 3.6 to $6.5(\mathrm{~s}=1.37)$ for the second time, respectively. The mean of the differences between the C.I. of the first and the second was $0.1 \pm$ $0.19 \mathrm{~L} . / \mathrm{min} . / \mathrm{M}^{2}$, and was not significantly different $(\mathrm{t}=0.526, \mathrm{P}>0.6)$.

The mean P-P time was 5.4 sec., with a range of 4.5 to $6.3(\mathrm{~s}=0.58)$ for the first time, and that of the second time was $5.2 \mathrm{sec}$., with a range of 4.3 to 6.0 $(s=0.46)$, respectively. The mean of the differences between the P-P times of the first and the second was $0.18 \pm 0.21 \mathrm{sec}$., and was not significantly different $(\mathrm{t}=0.86, \mathrm{P}>0.4)$.

Table I. Reproducibility

\begin{tabular}{|c|c|c|c|c|c|c|c|c|c|c|}
\hline Name & $\begin{array}{l}\text { Age } \\
\text { Sex }\end{array}$ & $\begin{array}{c}\text { BSA } \\
\text { M. }^{2}\end{array}$ & $\begin{array}{l}\text { Cardiac } \\
\text { output } \\
\text { L./min. }\end{array}$ & $\begin{array}{c}\text { Cardiac } \\
\text { index } \\
\text { L. } / \mathrm{min} . / \\
\mathrm{M.}^{2}\end{array}$ & $\begin{array}{c}\text { Peak-to- } \\
\text { peak } \\
\text { time } \\
\text { sec. }\end{array}$ & $\begin{array}{l}\text { Pulmo- } \\
\text { nary } \\
\text { blood } \\
\text { volume } \\
\text { ml./M. }\end{array}$ & $\begin{array}{l}\text { Cardiac } \\
\text { output } \\
\text { L./min. }\end{array}$ & $\begin{array}{c}\text { Cardiac } \\
\text { index } \\
\mathrm{L.} / \min . / \\
\mathrm{M}^{2}\end{array}$ & $\begin{array}{c}\text { Peak-to- } \\
\text { peak } \\
\text { time } \\
\text { sec. }\end{array}$ & $\begin{array}{c}\text { Pulmo- } \\
\text { nary } \\
\text { blood } \\
\text { volume } \\
\text { ml. } / \mathrm{M.}^{2}\end{array}$ \\
\hline I.C. & $43 \mathrm{M}$ & 1.43 & 8.5 & 5.9 & 5.5 & 545 & 9.3 & 6.5 & 4.8 & 520 \\
\hline K.S. & $77 \mathrm{~F}$ & 1.15 & 3.8 & 3.3 & 6.3 & 345 & 4.3 & 3.7 & 6.0 & 370 \\
\hline Y.M. & $35 \mathrm{~F}$ & 1.38 & 7.3 & 5.3 & 5.5 & 480 & 7.1 & 5.1 & 5.2 & 445 \\
\hline W.K. & $56 \mathrm{~F}$ & 1.50 & 5.3 & 3.5 & 5.4 & 315 & 5.6 & 3.8 & 5.0 & 310 \\
\hline I.H. & $40 \mathrm{~F}$ & 1.50 & 6.4 & 4.3 & 5.2 & 370 & 5.4 & 3.6 & 6.0 & 360 \\
\hline I.S. & $50 \mathrm{M}$ & 1.63 & 10.3 & 6.3 & 4.5 & 470 & 10.6 & 6.5 & 4.3 & 465 \\
\hline
\end{tabular}


The mean PBV of the first time was $420 \mathrm{ml} . / \mathrm{M}^{2}$, with a range of 315 to 545 $(\mathrm{s}=127)$, and that of the second time was $410 \mathrm{ml} . / \mathrm{M}^{2}$, with a range of 310 to $510(\mathrm{~s}=78)$. The mean of the differences between the PBV of the first and the second was $9.1 \pm 8.4 \mathrm{ml} . / \mathrm{M.}^{2}$, and was not significantly different $(t=1.08$, $\mathrm{P}>0.3)$.

\section{Normal subjects}

The control PBV was determined on 10 normal subjects. The mean of the C.I. was $4.0 \mathrm{~L} . / \mathrm{min} . / \mathrm{M} .{ }^{2}$, with a range of 2.3 to $5.1(s=0.86)$, that of the P-P time was 5.5 sec., with a range of 4.2 to $7.8(\mathrm{~s}=0.99)$, and that of the PBV was $360 \mathrm{ml} . / \mathrm{M.}^{2}$, with a range of 270 to $460(\mathrm{~s}=61)$, respectively. Changes

Table II. Normal Subjects

\begin{tabular}{|c|c|c|c|c|c|c|c|c|c|c|}
\hline \multicolumn{7}{|c|}{ Control } & \multicolumn{4}{|c|}{ After inhalation of Amyl Nitrite } \\
\hline Name & $\begin{array}{l}\text { Age } \\
\text { Sex }\end{array}$ & $\begin{array}{l}\text { BSA } \\
\text { M. }^{2}\end{array}$ & $\begin{array}{l}\text { Cardiac } \\
\text { output } \\
\text { L./min. }\end{array}$ & $\begin{array}{c}\text { Cardiac } \\
\text { index } \\
\text { L. } / \text { min. } / \\
\mathrm{M.}^{2}\end{array}$ & $\begin{array}{l}\text { Peak-to- } \\
\text { peak } \\
\text { time } \\
\text { sec. }\end{array}$ & $\begin{array}{c}\text { Pulmo- } \\
\text { nary } \\
\text { blood } \\
\text { volume } \\
\text { ml./M. }\end{array}$ & $\begin{array}{l}\text { Cardiac } \\
\text { output } \\
\text { L./min. }\end{array}$ & $\begin{array}{l}\text { Cardiac } \\
\text { index } \\
\text { L./min./ } \\
\mathrm{M.}^{2}\end{array}$ & $\begin{array}{c}\text { Peak-to- } \\
\text { peak. } \\
\text { time } \\
\text { sec. }\end{array}$ & $\begin{array}{c}\text { Pulmo- } \\
\text { nary } \\
\text { blood } \\
\text { volume } \\
\text { ml./M. }\end{array}$ \\
\hline T.T. & $36 \mathrm{M}$ & 1.68 & 6.1 & 3.6 & 6.0 & 360 & & & & \\
\hline N.M. & $19 \mathrm{M}$ & 1. 64 & 7.1 & 4.3 & 5.6 & 400 & & & & \\
\hline O.T. & $43 \mathrm{M}$ & 1.61 & 6.2 & 3.9 & 4.2 & 270 & & & & \\
\hline I.H. & $40 \mathrm{~F}$ & 1.50 & 6.4 & 4.3 & 5.2 & 370 & & & & \\
\hline U.K. & $46 \mathrm{M}$ & 1.50 & 7.7 & 5.1 & 4.4 & 370 & & & & \\
\hline H.M. & $23 \mathrm{M}$ & 1.63 & 3.8 & 2.3 & 7.8 & 305 & 5.2 & 3.2 & 4.2 & 220 \\
\hline K.H. & $22 \mathrm{M}$ & 1.46 & 4.4 & 3.0 & 5.4 & 270 & 4.5 & 3.1 & 5.0 & 260 \\
\hline S.K. & $35 \mathrm{~F}$ & 1.54 & 6.2 & 4.0 & 6.0 & 400 & 8.9 & 5.8 & 4.0 & 385 \\
\hline S.N. & $48 \mathrm{~F}$ & 1. 38 & 6.5 & 4.7 & 5.2 & 405 & 11.6 & 8.4 & 2.5 & 350 \\
\hline M.M. & $57 \mathrm{M}$ & 1,42 & 7.0 & 4.9 & 5.6 & 460 & 11.0 & 7.9 & 3.8 & 490 \\
\hline
\end{tabular}

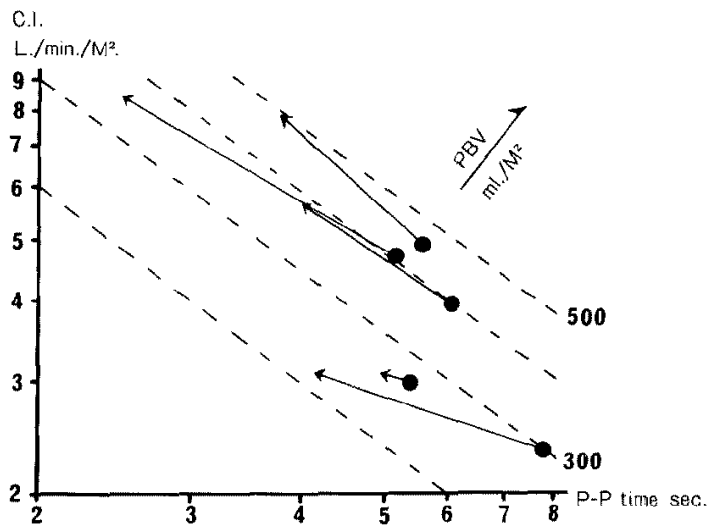

Fig. 1. Changes in cardiac index, P-P time and PBV induced by amyl nitrite in normal subjects. 
after the inhalation of amyl nitrite were determined on 5 subjects. The mean of the C.I. after the inhalation was $5.7 \mathrm{~L} . / \mathrm{min} . / \mathrm{M} .{ }^{2}$, with a range of 3.1 to $8.4(s=2.28)$, that of the P-P time was $3.9 \mathrm{sec}$., with a range of 2.5 to 5.0 $(\mathrm{s}=0.91)$, and that of the PBV was $340 \mathrm{ml} . / \mathrm{M} .{ }^{2}$, with a range of 220 to 490 $(s=107)$, respectively. The mean of C.I. after the inhalation increased significantly by $1.9 \pm 0.66(+50 \%) \quad \mathbf{L} . / \mathrm{min} . / \mathrm{M} .{ }^{2}(\mathrm{t}=2.88, \mathbf{P}<0.025)$ than the control. The mean of the P-P time after the inhalation decreased significantly by $2.1 \pm 0.53(-35 \%)$ sec. $(t=3.89, P<0.01)$ than the control. The difference in the means of PBV before and after the inhalation was $27 \pm 19.7(-7 \%)$ $\mathrm{ml} / \mathrm{M} .{ }^{2}$, and was not statistically different $(\mathrm{t}=1.37, \mathrm{P}>0.2)$.

\section{Mitral stenosis}

The inhalation of amyl nitrite was performed on 9 patients with mitral stenosis.

The mean C.I. before the inhalation was $3.43 \mathrm{~L} . / \mathrm{min} . / \mathrm{M} .{ }^{2}$, with a range of 2.5 to $4.9(\mathrm{~s}=0.81)$, and that after the inhalation was $4.24 \mathrm{~L} . / \mathrm{min} . / \mathrm{M} .{ }^{2}$, with a range of 3.2 to $5.4(s=0.86)$, respectively. The mean C.I. after the inhalation increased significantly by $0.81 \pm 0.15(+23 \%) \mathrm{L}$. $/ \mathrm{min} . / \mathrm{M} .{ }^{2}(\mathrm{t}=5.50, \mathrm{P}<0.0005)$ than the control.

The mean P-P time before the inhalation was $7.86 \mathrm{sec}$, with a range of 6.0 to $10.0(s=1.39)$, and that after the inhalation was $5.91 \mathrm{sec}$, with a range of 4.0 to $7.5(\mathrm{~s}=1.13)$, respectively. The mean P-P time after the inhalation decreased significantly by $1.94 \pm 0.39(-20 \%)$ sec. $(t=4.98, P<0.0025)$ than the control.

The mean PBV before the inhalation was $440 \mathrm{ml} . / \mathrm{M}^{2}$, with a range of

Table III. Mitral Stenosis

\begin{tabular}{|c|c|c|c|c|c|c|c|c|c|c|}
\hline \multicolumn{7}{|c|}{ Control } & \multicolumn{4}{|c|}{ After Inhalation of Amyl Nitrite } \\
\hline Name & $\begin{array}{l}\text { Age } \\
\text { Sex }\end{array}$ & $\begin{array}{c}\text { BSA } \\
\text { M. }^{2}\end{array}$ & $\begin{array}{l}\text { Cardiac } \\
\text { output } \\
\text { L./min. }\end{array}$ & $\begin{array}{c}\text { Cardiac } \\
\text { index } \\
\text { L. } / \text { min. } / \\
\mathrm{M.}^{2}\end{array}$ & $\begin{array}{c}\text { Peak-to- } \\
\text { peak } \\
\text { time } \\
\text { sec. }\end{array}$ & $\begin{array}{c}\text { Pulmo- } \\
\text { nary } \\
\text { blood } \\
\text { volume } \\
\text { ml./M. }{ }^{2}\end{array}$ & $\begin{array}{l}\text { Cardiac } \\
\text { output } \\
\text { L. } / \text { min. }\end{array}$ & $\begin{array}{c}\text { Cardiac } \\
\text { index } \\
\text { L. } / \text { min. } / \\
\mathrm{M.}^{2}\end{array}$ & $\begin{array}{c}\text { Peak-to- } \\
\text { peak } \\
\text { time } \\
\text { sec. }\end{array}$ & $\begin{array}{c}\text { Pulmo- } \\
\text { nary } \\
\text { blood } \\
\text { volume } \\
\text { ml. } / \mathrm{M}^{2}\end{array}$ \\
\hline Y.Y. & $40 \mathrm{~F}$ & 1.48 & 4.1 & 2.8 & 8.7 & 400 & 4.9 & 3.3 & 7.0 & 390 \\
\hline S.K. & $46 \mathrm{~F}$ & 1.52 & 7.4 & 4.9 & 6.6 & 540 & 7.6 & 5.0 & 6.3 & 525 \\
\hline T.H. & $40 \mathrm{~F}$ & 1.35 & 4.6 & 3.4 & 6.8 & 385 & 5.5 & 4.1 & 5.2 & 350 \\
\hline Y.K. & $74 \mathrm{M}$ & 1.62 & 5.2 & 3.2 & 7.0 & 375 & 6.8 & 4.2 & 5.0 & 350 \\
\hline S.T. & $45 \mathbf{M}$ & 1.43 & 3.5 & 2.5 & 7.8 & 320 & 4.6 & 3.2 & 6.8 & 365 \\
\hline H.J. & $32 \mathrm{M}$ & 1.62 & 5.5 & 3.4 & 10.0 & 560 & 8.3 & 5.1 & 6.2 & 530 \\
\hline T.Y. & $45 \mathrm{~F}$ & 1.32 & 3.3 & 2.5 & 8.8 & 370 & 4.2 & 3.2 & 7.5 & 400 \\
\hline K.S. & $36 \mathrm{~F}$ & 1.51 & 6.6 & 4.3 & 6.0 & 430 & 8.2 & 5.4 & 4.0 & 360 \\
\hline T.S. & $39 \mathrm{~F}$ & 1.39 & 5.4 & 3.9 & 9.0 & 580 & 6.5 & 4.7 & 5.2 & 400 \\
\hline
\end{tabular}




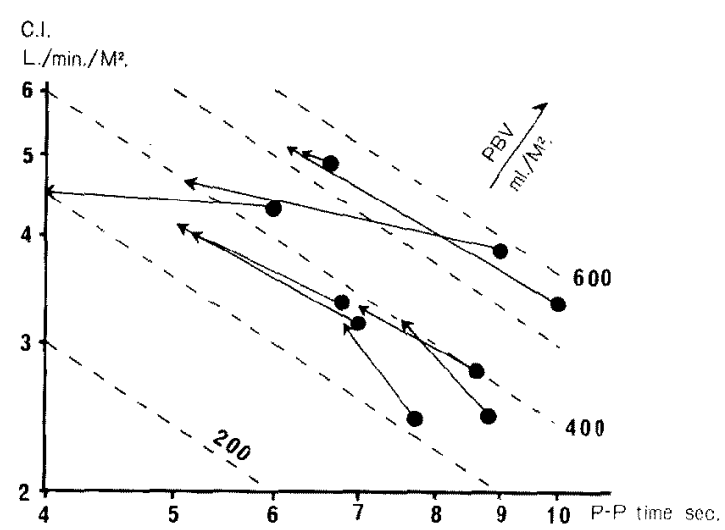

Fig. 2. Changes in cardiac index, P-P time and PBV induced by amyl nitrite in mitral stenosis.

320 to $580(\mathrm{~s}=95)$, and that after the inhalation was $407 \mathrm{ml} . / \mathrm{M.}{ }^{2}$, with a range of 350 to $530(s=67.7)$, respectively. The mean PBV after the inhalation decreased by $32.2 \pm 21.7(-7 \%) \mathrm{ml} . / \mathrm{M}^{2}$ than the control, though, the difference was not statistically significant $(t=1.48, \mathrm{P}>0.1)$.

\section{Coronary heart disease}

The inhalation of amyl nitrite was performed on 13 patients with coronary heart disease.

Table IV. Coronary Heart Disease

\begin{tabular}{|c|c|c|c|c|c|c|c|c|c|c|}
\hline \multicolumn{7}{|c|}{ Control } & \multicolumn{4}{|c|}{ After Inhalation of Arnyl Nitrite } \\
\hline Name & $\begin{array}{l}\text { Age } \\
\text { Sex }\end{array}$ & $\begin{array}{c}\text { BSA } \\
\text { M. }^{2}\end{array}$ & $\begin{array}{c}\text { Cardiac } \\
\text { output } \\
\text { L./min. }\end{array}$ & $\begin{array}{l}\text { Cardiac } \\
\text { index } \\
\text { L.min./ } \\
\mathrm{M.}^{2}\end{array}$ & $\begin{array}{c}\text { Peak-to- } \\
\text { peak } \\
\text { time } \\
\text { sec. }\end{array}$ & $\begin{array}{c}\text { Pulmo- } \\
\text { nary } \\
\text { blood } \\
\text { volume } \\
\mathrm{ml} / \mathrm{M}^{2}\end{array}$ & $\begin{array}{c}\text { Cardiac } \\
\text { output } \\
\text { L./min. }\end{array}$ & $\begin{array}{l}\text { Cardiac } \\
\text { index } \\
\mathrm{L} . / \mathrm{min} . / \\
\mathrm{M.}^{2}\end{array}$ & $\mid \begin{array}{c}\text { Peak-to- } \\
\text { peak } \\
\text { time } \\
\text { sec. }\end{array}$ & $\begin{array}{l}\text { Pulmo- } \\
\text { nary } \\
\text { blood } \\
\text { volume } \\
\text { ml. } / \mathbf{M .}^{2}\end{array}$ \\
\hline N.Y. & $50 \mathrm{M}$ & 1.50 & 6.3 & 4.2 & 7.6 & 530 & 9.8 & 6.5 & 4.4 & 480 \\
\hline Y.Y. & $65 \mathrm{M}$ & 1.55 & 5.0 & 3.2 & 5.0 & 270 & 8.4 & 5.4 & 5.4 & 490 \\
\hline $\mathrm{K} . \mathrm{K}$. & $63 \mathrm{~F}$ & 1.27 & 3.4 & 2.7 & 5.0 & 230 & 6.0 & 4.7 & 5.2 & 410 \\
\hline K.K. & $60 \mathrm{M}$ & 1.54 & 5.3 & 3.4 & 7.0 & 400 & 11.0 & 7.2 & 5.2 & 620 \\
\hline M.I. & $65 \mathrm{M}$ & 1.72 & 4.9 & 2.8 & 8.0 & 380 & 7.2 & 4.2 & 6.4 & 445 \\
\hline S.T. & $59 \mathrm{M}$ & 1.77 & 5.6 & 3.2 & 6.0 & 320 & 6.9 & 3.9 & 6.0 & 390 \\
\hline K.E. & $63 \mathrm{M}$ & 1.47 & 4.8 & 3.3 & 5.2 & 280 & 5.7 & 3.9 & 3.1 & 200 \\
\hline $\mathrm{K} . \mathrm{H}$ & $66 \mathrm{M}$ & 1.48 & 5.9 & 4.0 & 5.8 & 390 & 8.2 & 5.6 & 5.0 & 460 \\
\hline Y.K. & $55 \mathrm{M}$ & 1.56 & 7.1 & 4.5 & 6.4 & 480 & 10.2 & 6.5 & 4.3 & 470 \\
\hline K.S. & $77 \mathrm{~F}$ & 1.15 & 3.8 & 3.3 & 6.3 & 345 & 4.3 & 3.7 & 6.0 & 370 \\
\hline N.S. & $41 \mathrm{M}$ & 1.63 & 10.7 & 6.6 & 3.7 & 405 & 12.8 & 7.9 & 3.4 & 445 \\
\hline N.K. & $72 \mathrm{M}$ & 1.59 & 6.0 & 3.8 & 5.8 & 370 & 9.4 & 5.9 & 5.4 & 530 \\
\hline H.W. & $69 \mathrm{M}$ & 1.38 & 9.4 & 6.8 & 4.0 & 450 & 9.3 & 6.7 & 4.0 & 450 \\
\hline
\end{tabular}




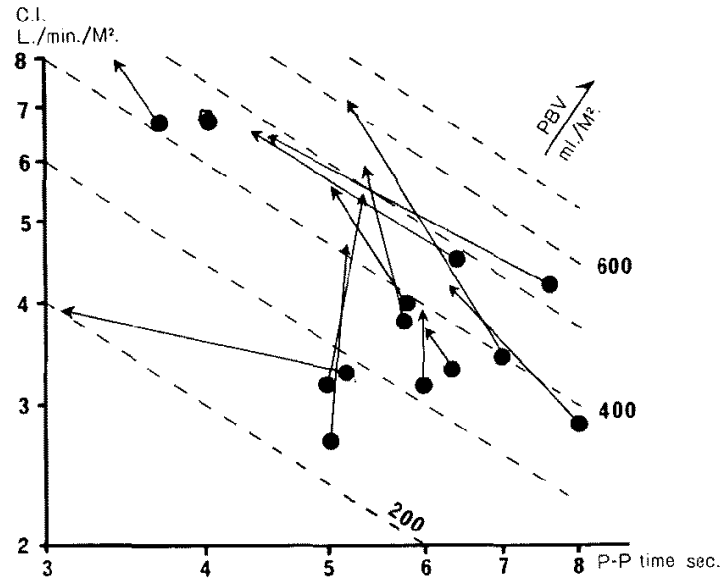

Fig. 3. Changes in cardiac index, P-P time and PBV induced by amyl nitrite in coronary heart disease.

The mean C.I. before the inhalation was $4.0 \mathrm{~L} . / \mathrm{min} . / \mathrm{M}^{2}$, with a range of 2.7 to $6.8(\mathrm{~s}=1.3 \mathrm{l})$, and that after the inhalation was $5.6 \mathrm{~L} . / \mathrm{min} . / \mathrm{M} .^{2}$, with a range of 3.7 to $7.9(\mathrm{~s}=2.0)$, respectively. The C.I. after the inhalation increased significantly by $1.6 \pm 0.47(+40 \%) \mathrm{L} . / \mathrm{min} . / \mathrm{M} .^{2},(\mathrm{t}=3.31, \mathrm{P}<0.005)$ than the control.

The mean P-P time before the inhalation was 5.8 sec., with a range of 3.7 to $8.0(\mathrm{~s}=1.27)$, and that after the inhalation was $4.9 \mathrm{sec}$, with a range of 3.1 to $6.4(\mathrm{~s}=1.01)$, respectively. The P-P time after the inhalation decreased significantly by $0.9 \pm 0.31(-16 \%)$ sec. $(\mathrm{t}=3.03, \mathrm{P}<0.01)$ than the control.

The mean PBV before the inhalation was $374 \mathrm{ml} . / \mathrm{M.}^{2}$, with a range of 230 to $530(\mathrm{~s}=85)$, and that after the inhalation was $443 \mathrm{ml} . / \mathrm{M}^{2}$, with a range of 200 to 620 ( $s=97$ ), respectively. The PBV after the inhalation increased significantly by $70 \pm 27(+19 \%) \mathrm{ml} . / \mathrm{M}^{2}(\mathrm{t}=2.56, \mathrm{P}>0.025)$ than the control.

Normal us. mitral stenosis at rest

There is no significant difference in C.I. $(t=1.498, P>0.1)$. The P-P time in mitral stenosis is significantly longer than the normal by $2.32 \mathrm{sec}$. $(t=4.35, \mathrm{P}<0.0005)$. The PBV in mitral stenosis is also significantly increased over the normal by $79 \mathrm{ml} . / \mathrm{M.}^{2},(\mathrm{t}=2.175, \mathrm{P}<0.025)$.

Normal vs. coronary heart disease

There is no significant difference in C.I. $(t=0.06, P>0.9)$, P-P time $(\mathrm{t}=0.99, \mathrm{P}>0.3)$, and $\mathrm{PBV}(\mathrm{t}=0.701, \mathrm{P}>0.4)$, respectively. 


\section{Discussion}

\section{Reproducibility}

RGG was performed in duplicate to evaluate the reproducibility. As to C.I., the mean of the difference was $0.1 \pm 0.19 \mathrm{~L} . / \mathrm{min} . / \mathrm{M} .^{2}$, and was not significantly different. As to the P-P time, the mean of the difference was $0.18 \pm$ $0.21 \mathrm{sec}$, and was not significantly different. As to PBV, the mean of the difference was $9.1 \pm 8.4 \mathrm{ml} . / \mathrm{M.}^{2}$, and was not significantly different. The cardiac output by Fick method may change as much as $\pm 25 \%$ in almost the same condition. Considering these figures, the reproducibility of RCG was very satisfactory.

Pulmonary blood volume at rest

There was no significant difference in cardiac index among 3 groups.

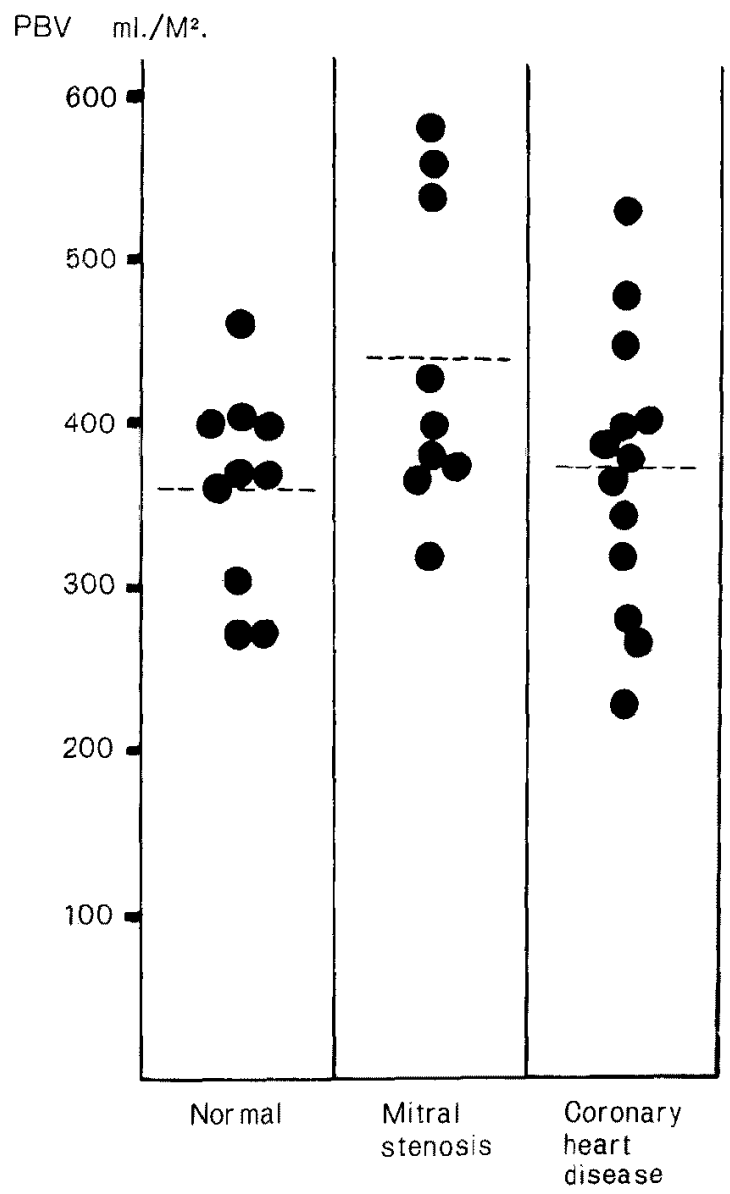

Fig. 4. Pulmonary blood volume in each group. 
The PBV was almost the same in the normal and the coronary heart disease group. However, in mitral stenosis, there was a significant increase in PBV, which resulted from the elongation of the pulmonary circulation time. The increased PBV in mitral stenosis is in accordance with the past literature (Fig. 4). ${ }^{1-4), 7), 8)}$

\section{Effect of amyl nitrite}

It is a well-known fact that the inhalation of amyl nitrite causes a rapid and transient circulatory change. The effects of amyl nitrite upon the systemic circulation are rather well established, ${ }^{9-11)}$ although the exact effects of amyl nitrite on the vessels are still unsettled. On the other hand, the knowledge concerning its effects on pulmonary circulation is very limited. The effects on the normal human pulmonary circulation of amyl nitrite have been reported mainly by de Leon et al. ${ }^{12)}$ Kot et al. ${ }^{13)}$ reported its effects on the hemodynamics of the isolated lung lobe in the dog. The facts being reported in the past are as follows: (1) a marked increase in blood flow which is primarily rate related, (2) a profound decline in total systemic resistance resulting in a decrease in left ventricular stroke work, but no change in left ventricular minute work, (3) a less profound decline in total pulmonary resistance, (4) a small but significant rise in pulmonary systolic and mean pressures, (5) an increase in effective right ventricular minute and stroke work, and (6) a direct dilating effect on pulmonary vessels and a decrease in pulmonary vascular resistance.

In cases without an intracardiac left to right shunt, the concentration of the inhaled amyl nitrite reaching the pulmonary artery in the recirculating venous blood is thought to be too low to act as a dilator of the pulmonary artery. Prior to this study, we observed pulmonary arterial pressure changes with a catheter before and after the inhalation of amyl nitrite. The tendency of the pressure to change soon after the inhalation of amyl nitrite was variable. However, the elevation of the systolic pressure and the increase in the pulse pressure of the pulmonary artery pressure curve were recorded in all cases 30 through 50 to $60 \mathrm{sec}$. after the beginning of $20 \mathrm{sec}$. of the inhalation. This rise in the pressure is supposed to have resulted from the increased venous return due to increased cardiac output.

The pulmonary blood volume in this study was determined during the above mentioned phase with increascd venous return. This phase is thought to be approximately the same phase in which de Leon et al. performed their study.

In this study, the results are as follows. Cardiac output increased significantly in all groups, but the increase in the mitral stenosis cases was less than in the others. The significant decrease in P-P time revealed an increase 
in the velocity of the pulmonary circulation. The pulmonary blood volume revealed no change before and after the inhalation in the normal and in the mitral stenosis. Only in coronary heart disease was the pulmonary blood volume increased significantly.

From these facts, it appears that the inhalation of amyl nitrite does not dilate the pulmonary vessels positively in the normal and the mitral stenosis patient at least during the studied period.

In normal subject, the function of the left ventricle is enough to eject the increased venous return without any rise in left ventricular enddiastolic and left atrial pressures. Pulmonary veins need not dilate in order to accommodate an increased flow rate, and pulmonary blood volume remains unchanged.

In mitral stenosis, an increase in cardiac output after the inhalation of amyl nitrite is less marked than in the others, because of the stenosed mitral valve. In most cases of mitral stenosis, the mean left atrial pressure rises after the inhalation of amyl nitrite. ${ }^{14)}$ However, pulmonary blood volume and pulmonary venous pressure in mitral stenosis are already elevated at rest, so that pulmonary veins are suspected to be in a state of less distensibility, and it seems therefore more difficult to dilate instantly with the pressure rise.

In coronary heart disease, the left atrial pressure rise after the inhalation of amyl nitrite would be more than that of normal subjects because of impaired left ventricular reserve. Pulmonary veins may distend more easily against pressure increase than in mitral stenosis. These factors may be responsible for the increase in pulmonary blood volume after the inhalation of amyl nitrite in coronary heart disease. On the other hand, our " pulmonary blood volume" theoretically includes a part of the left and right heart cavity. De Leon et al. suggested that the inhalation of amyl nitrite increased right ventricular minute work with left ventricular minute work remaining unchanged. If the response of the heart in these disease states is identical to that found in their report, the increase in the residual volume of the right heart might also relate to the increase in pulmonary blood volume after the inhalation of amyl nitrite in coronary heart disease.

\section{ACKNOWLEDGEMENT}

The author would like to express his appreciation to Drs. K. Machii, M. Kashima, H. Sekiguchi, T. Matsuzaki and K. Kohno for their cooperation in this study, and to Miss M. Mikawa for the technical assistance.

\section{ReFERENCES}

1. Kunieda, R. : Respiration \& Circulation 3:44, 1955 (in Japanese).

2. Milnor, W. R., Jose, I. D., and Meguff, C. J. : Circulation 22 : 130, 1960. 
3. Dock, D. S., Kraus, W. L., McGuire, L. B., Hyland, J. W., Haynes, F. W., and Dexter, L. : J. Clin. Invest. $40: 317,1961$.

4. Levinson, G. E., Frank, M. J., and Hellems, H. K. : Am. Heart J. 67 : 734, 1964.

5. Schreiner, B. F., Murphy, G. W., and Yu, P. N.: Circulation 34: 249, 1966.

6. Giuntini, G., Lewis, M. L., Luis, A. S., and Harvey, R. M. : J. Clin. Invest. 42: 1589, 1963.

7. Roy, S. B., Bhardwaj, P., and Bhatia, M. L. : Brit. Med. J. 2: 1466, 1965.

8. Gazioglu, K. G. and Yu, P. N. : Circulation $35: 701,1967$.

9. Beck, W., Schrire, V., Vogelpoel, L., Nellen, M., and Swanepoel, A.: Am. J. Cardiol. 8: $341,1961$.

10. Perloff, J. K., Calvin, J., De Leon, A. C., and Bowen, P.: Am. Heart J. 66 : 460, 1963.

11. Mason, D. T. and Braunwald, E.: Circulation 32: 755, 1965.

12. De Leon, A. C. and Perloff, J. K. : Am. Heart J. $72: 337,1966$.

13. Kot, P. A. and Humpert, E. L. : Proc. Soc. Exp. Biol. Med. 127: 368, 1968.

14. Endrys, J., Belobradek, Z., Petrle, M., and Steinhart, L. : Brit. Heart J. 26 : 250, 1964. 